\title{
KETERAMPILAN SOSIAL PESERTA DIDIK DALAM PEMBELAJARAN TEMATIK DI KELAS V MI MUHAMMADIYAH SELO KULON PROGO
}

\author{
Chafidhatul Ulum
}

MI Muhammadiyah Selo, Kulon Progo

Email: chafikiya@yahoo.com

\begin{abstract}
ABSTRAK
Keterampilan sosial peserta didik mempunyai peran yang sangat penting dalam sebuah pembelajaran. Penelitian ini bertujuan untuk mendeskripsikan bagaimana keterampilan sosial peserta didik dalam pembelajaran tematik di kelas V MI Muhammadiyah Selo Kulon Progo. Jenis metode penelitian ini adalah penelitian kualitatif. Hasil penelitian menunjukkan bahwa pertama, implementasi pembelajaran tematik dilaksanakan melalui tiga tahapan yaitu yaitu tahap perencanaan yang meliputi mengambil tema dari Kemendikbud RI, mengecek/ melihat SKL, KI, KD, melakukan Pemetaan KI,KD, membuat jaringan tema, menyusun silabus, dan merancang RPP, tahap pelaksanaan meliputi kegiatan pendahuluan, kegiatan inti, dan kegiatan penutup, dan tahap evaluasi. Kedua, keterampilan sosial peserta didik meliputi keterampilan bekerja sama dengan orang lain, keterampilan mengontrol diri dan keterampilan berbagi pikiran dan pengalaman dengan orang lain. Ketiga, faktor pendukung pengembangan keterampilan sosial peserta didik adalah guru, peserta didik, dan lingkungan. Faktor penghambatnya yaitu belum terpenuhinya sarana prasarana madrasah, dan distribusi sumber belajar terlambat. Keempat, dampak pengembangan keterampilan sosial peserta didik yaitu sikap disiplin, tanggung jawab, dan peduli terhadap orang lain.
\end{abstract}

Kata Kunci: Keterampilan Sosial, Peserta Didik, Pembelajaran Tematik.

AL-BIDAYAH: Jurnal Pendidikan Dasar Islam

Volume 10, Nomor 02, Desember 2018; P-ISSN: 2085-0034, E-ISSN: 2549-3388 


\section{ABSTRACT}

Learners' social skill has an important role in learning process. This research aims to describe learners' social skill in thematic learning in Grade V of MI Muhammadyah Selo, KulonProgo. This research is qualitative descriptive. The results of study indicate that, first, the implementation of thematic learning in Grade $V$ is conducted through three steps. The first step is planning consisting of taking theme from the Ministry of Education and Culture of Republic of Indonesia; checking SKL, KI, and KD; mapping the KI and KD; making theme network; arranging syllabus; and designing RPP. The second step is implementation consisting of introduction, main activities, and closing. Meanwhile, the last step is evaluation. Second, learners' social skill consists of: skill of collaborating with others, self-control skill, and skill of sharing thoughts and experience with others. Third, supporting factors for developing learners'social skill are teacher and environment. Meanwhile, the obstacle is that Madrasah's facilities and infrastructure have not been provided well, so the distribution of learning source takes long time. Fourth, the impact of the development of learners' social skill, namely discipline, responsibility, and caring for others.

\section{Keywords: $\quad$ Social Skill, Learners', Thematic Learning}

\section{A. PENDAHULUAN}

Kurikulum 2013 disusun untuk menyempurnakan kekurangan-kekurangan pada kurikulum sebelumnya. Dalam Standar Kompetensi Kelulusan (SKL) Kurikulum 2013 meliputi pendidikan karakter, metodologi pembelajaran aktif, dan keseimbangan antara soft skill dan hard skill yang mencakup tiga aspek yaitu, aspek kognitif (pengetahuan), aspek afektif (sikap), dan aspek psikomotorik (keterampilan) secara terpadu. Kurikulum 2013 untuk SD/MI menggunakan pendekatan tematik terpadu dari kelas satu sampai kelas enam. Hal tersebut didasarkan pada tahap perkembangan anak usia SD/MI yaitu pada tahap operasional konkret, terpadu, dan hierarki.

Menurut Kurikulum 2013 dalam pembelajaran tematik, guru bukanlah satusatunya sumber belajar. Guru diharapkan menjadi fasilitator, pembimbing, konsultan, dan mitra belajar daripada sekedar mentransfer pengetahuan kepada siswa. Hal ini sesuai dengan Undang-undang Nomor 14 Tahun 2005 tentang Guru dan Dosen yang 
menyebut guru adalah pendidik profesional dengan tugas utama mendidik, mengajar, membimbing, mengarahkan, melatih, menilai, dan mengevaluasi peserta didik pada pendidikan usia dini jalur pendidikan formal, pendidikan dasar, dan pendidikan menengah. ${ }^{1}$

Sebagai respon terhadap tugas utama guru tersebut di atas, maka diperlukan pendidikan yang manusiawi, yaitu pendidikan yang ujungnya adalah sebagai proses pembudayaan yang didalamnya terbangun karakter kemanusiaan yang terampil dalam kehidupan bermasyarakat seperti saling menghargai antar sesama manusia sebagai makhluk Tuhan. Sebagaimana dinyatakan oleh Zamroni sebagai berikut: ${ }^{2}$

Humanisasi pendidikan untuk mewujudkan pendidikan yang manusiawi merupakan suatu upaya menjadikan pendidikan sebagai proses pembudayaan. Oleh karena itu, tujuan pendidikan tiada lain adalah untuk mengembangkan jasmani, mensucikan rohani dan menumbuhkan akal. Sehubungan dengan itu, maka hasil pendidikan mencakup 2 level: individu dan kelompok. Pada level individu, hasil pendidikan adalah terwujudnya individu yang memiliki akal yang cerdas, jasmani yang sehat dan kuat, serta rohani yang suci, sehingga menjadi warga negara yang baik dan keberadaannya akan bermanfaat tidak saja bagi diri pribadi tetapi juga bagi lingkungan, masyarakat bangsa dan negara. Pada level kelompok, maka hasil pendidikan adalah ummatan washaton, khaira ummah.

Dari pernyataan tersebut di atas dapat diketahui bahwa keberhasilan suatu pendidikan tidak hanya diukur dari pencapaian kognitif saja, tetapi yang lebih penting juga adalah segi afektif dan psikomotorik. Sikap saling menghormati dan menghargai dalam interaksi sosial baik di dalam sekolah maupun di luar sekolah seharusnya juga perlu mendapatkan perhatian. Oleh karenanya, keterampilan sosial sangat perlu ditanamkan di dalam diri peserta didik di sekolah.

Dalam sebuah penelitian di Harvard University, ditemukan bahwa kesuksesan seseorang tidak ditentukan semata-mata oleh pengetahuan dan keterampilan teknis (hard skill), akan tetapi juga ditentukan oleh kemampuan mengolah diri dan orang lain (soft skill). Bahkan kesuksesan hanya ditentukan 20\% dari hard skill dan sisanya

1. Undang-Undang Republik Indonesia Nomor 14 Tahun 2005 tentang Guru dan Dosen, hlm. 2.

2. Zamroni, Pendidikan dan Demokrasi dalam Transisi (Prakondisi menuju Era Globalisasi) (Jakarta: PSAP, 2007), hlm. 185-186. 
80\% dari soft skill. ${ }^{3}$ Oleh karena itu, dalam Kurikulum 2013 proses pembelajaran dengan pendekatan tematik terpadu akan menumbuhkembangkan keterampilan sosial peserta didik, sehingga dapat berkembang secara optimal.

Sebagai makhluk sosial, manusia senantiasa membutuhkan orang lain untuk memenuhi kebutuhan hidupnya. Manusia melalui akalnya menciptakan pengetahuan sebagai alat untuk beradaptasi dengan lingkungan. Keterampilan berpikir dan berdaya nalar, keterampilan hidup bersama, keterampilan bekerja, dan keterampilan pengendalian diri (emosi, perasaan) merupakan keterampilan dasar untuk bertahan dan menjalani kehidupan. Keterampilan tersebut dimiliki semua orang, hanya dalam pengembangannya masing-masing individu berbeda. Usaha untuk mengembangkan keterampilan sosial secara optimal dan efektif dilakukan melalui proses pendidikan.

Keterampilan sosial adalah kemampuan untuk menciptakan hubungan sosial yang serasi dan memuaskan berbagai pihak, dalam bentuk penyesuaian terhadap lingkungan sosial dan keterampilan memecahkan masalah sosial. Dalam keterampilan sosial tercakup kemampuan mengendalikan diri, adaptasi, toleransi, berkomunikasi, berpartisipasi dalam kehidupan masyarakat. Cartledge dan Milburn menyatakan bahwa keterampilan sosial merupakan perilaku yang perlu dipelajari, karena memungkinkan individu dapat berinteraksi, memperoleh respon positif atau negatif, karena itu keterampilan sosial merupakan kompetensi yang sangat penting untuk dimiliki setiap orang termasuk di dalamnya peserta didik, agar dapat memelihara 3 hubungan sosial secara positif dengan keluarga, teman sebaya, masyarakat dan lingkungan yang lebih luas. ${ }^{4}$

Rosalina, dkk (dalam jurnal pendidikan dan pembelajaran) menyatakan bahwa dengan mengaplikasikan pembelajaran tematik dapat mengembangkan keterampilan sosial peserta didik. Hal ini, penting untuk mengaplikasikan pembelajaran tematik pada proses pembelajaran. Karena pembelajaran tematik berorientasi pada keterampilan sosial yang membawa anak untuk lebih kreatif, berani berbicara, mengungkapkan setiap permasalahan yang dihadapi sekaligus menemukan penyelesaian yang adaptif. ${ }^{5}$

3. Hardi Utomo, "Kontribusi soft skill dalam Menumbuhkan Jiwa Kewirausahaan," Jurnal Among Makarti, Vol. 3, No. 5 Juli 2010.

4. Enok Maryani, "Pengembangan Program Pembelajaran IPS Untuk Meningkatkan Keterampilan Sosial Siswa," Jurnal Penelitian, Vol. 9, No. 1, April 2019, hlm. 8.

5. Rossi Rosalina, Marzuki, dan Mastar Asran, "Aplikasi Pembelajaran Tematik dalam Pengembangan Keterampilan Sosial dan Manajemen Perilaku Diri di Kelas I," Jurnal Pendidikan dan Pembelajaran, Vol. 4, No. 8, Agustus 2015, http://jurnal.untan.ac.id/ index.php/jpdpb/article/view/11110/10559. hlm. 1 - 5 
Keterampilan sosial merupakan hal yang sangat penting dalam pembelajaran. Karena, keterampilan sosial adalah salah satu modal peserta didik untuk dapat berinteraksi dengan orang lain. Jika seseorang tidak memiliki keterampilan sosial maka dia tidak akan bisa membawa diri dalam lingkungannya. Sebaliknya, jika seseorang memiliki keterampilan sosial yang tinggi dia akan mampu bekerja sama dengan orang lain. Selain itu seseorang yang memiliki keterampilan sosial yang tinggi juga akan memiliki rasa empati terhadap sesama dan bisa menemukan jalan keluar (solusi) atas permasalahan yang dihadapi.

Fenomena yang ada selama ini keterampilan sosial yang dimiliki oleh masyarakat pada umumnya masih rendah. Hal ini diperkuat dari data yang diperoleh dari Komisi Perlindungan Anak Indonesia (KPAI) dalam jangka waktu tahun 2011 sampai 2017 KPAI telah menerima 26 ribu kasus anak yang berhadapan dengan hukum. Salah satu contohnya adalah kasus bullying yang terjadi di Thamrin City seperti yang dilansir oleh detiknews 4 Oktober 2017. Selain hal itu masih banyak deretan masalah sosial yang terjadi, seperti perkelahian pelajar, narkoba dan minuman keras, kecurangan dalam ujian, korupsi, pornografi, dan berbagai tindakan tidak baik lainnya. Berbagai permasalahan sosial tersebut terjadi sebagai bentuk lemahnya keterampilan sosial dalam lingkup individu, keluarga, masyarakat, bahkan negara.

Berdasarkan hasil wawancara dengan Kepala Madrasah, bahwa MI Muhammadiyah Selo Kulon Progo adalah salah satu madrasah yang telah menerapkan pembelajaran tematik dengan mengacu pada Kurikulum 2013 sejak tahun pelajaran 2016/2017. Pembelajaran tematik dilaksanakan secara bertahap setiap tahun pelajaran. Pada tahun pelajaran 2016/2017 kurikulum 2013 diterapkan di kelas I dan IV, kemudian tahun pelajaran 2017/2018 untuk kelas I, II, IV, dan V. Dan pada tahun pelajaran 2018/2019 pembelajaran tematik dengan mengacu pada Kurikulum 2013 sudah diterapkan pada semua kelas yaitu dari kelas satu sampai dengan kelas enam. ${ }^{6}$

Dari hasil observasi yang telah dilakukan oleh peneliti di kelas V MI Muhammadiyah Selo Kulon Progo, pembelajaran tematik terpadu yang dilaksanakan sudah mengarah pada tuntasnya kegiatan pembelajaran tematik dan mengarahkan pada pengembangan keterampilan sosial peserta didik. Dalam proses pembelajaran tematik di kelas terlihat kerjasama yang baik diantara peserta didik. Selain itu juga tampak peserta didik mampu menyampaikan pendapatnya, mampu melibatkan diri

6. Hasil wawancara dengan Bapak Suryono,S.Pd.I Kepala MI Muhammadiyah Selo Kulon Progo tanggal 8 Agustus 2018. 
dalam kelompok kerjanya serta berani mengajukan pertanyaan ketika ada hal yang kurang dipahami oleh peserta didik.

Selain itu guru sudah memahami bagaimana cara menstimulus peserta didik agar mau mengajukan pertanyaan dalam proses pembelajaran sehingga dapat mendorong peserta didik untuk berpikir dan mengungkapkan pendapatnya. Selain itu dalam proses pembelajaran guru menggunakan berbagai metode yang bisa mengembangkan keterampilan sosial peserta didik. Guru menggunakan strategi cooperatif learning dalam proses pembelajaran supaya semua peserta didik dapat terlibat aktif setiap proses pembelajaran.

Dari uraian di atas terlihat bahwa MI Muhammadiyah Selo Kulon Progo merupakan salah satu lembaga yang siap melaksanakan kebijakan Kurikulum 2013, dengan mengimplementasikan pembelajaran tematik untuk mengembangkan keterampilan sosial peserta didik. Untuk itu penelitian ini bertujuan untuk memberikan gambaran pada sekolah/ madrasah dalam mengimplementasikan pembelajaran tematik untuk mengembangkan keterampilan sosial peserta didik. Oleh karena itu peneliti terdorong untuk membuat penelitian tentang "Keterampilan Sosial Peserta Didik Dalam Pembelajaran Tematik Di Kelas V MI Muhammadiyah Selo Kulon Progo“. Peneliti beranggapan bahwa peserta didik kelas V MI berada pada tahap operasional konkret yang membutuhkan pengalaman riil. Pendidikan pada usia ini menjadi kesempatan yang sangat penting untuk mengembangkan keterampilan sosial peserta didik sebagai bekal ketika dewasa nanti.

\section{B. METODE PENELITIAN}

Penelitian ini merupakan penelitian kualitatif, yaitu penelitian bermaksud untuk memahami fenomena tentang apa yang dialami oleh subyek penelitian, seperti perilaku, persepsi, tindakan dan lain-lain secara holisitik, dan dengan cara deskripsi dalam bentuk kata-kata dan bahasa, pada suatu konteks khusus yang alamiah dan dengan memanfaatkan berbagai metode ilmiah. ${ }^{7}$ Teknik pengumpulan data yang digunakan dalam penelitian ini adalah observasi, wawancara, dan dokumentasi. Subjek penelitian yang dipilih peneliti dengan menggunakan purposive sampling yaitu kepala, guru kelas, dan peserta didik kelas V MI Muhammadiyah Selo Kulon Progo. Tahapan dalam analisis data yaitu reduksi data, penyajian data dan penarikan kesimpulan.

7. Moleong Lexy J, Metodologi Penelitian Kualitatif (Bandung: PT. Remaja Rosdakarya, 2009), hlm. 26. 


\section{HASIL PENELITIAN DAN PEMBAHASAN}

\section{Implementasi Pembelajaran Tematik}

Inovasi pendidikan di bidang kurikulum diharapkan secara periodik dapat dilakukan untuk kepentingan mengubah dan memperbaiki cara belajar dan membelajarkan materi kepada peserta didik. Pembelajaran yang dimaksud diharapkan dapat memberikan pelayanan yang bersifat perbaikan sesuai dengan potensi, tahap perkembangan dan kondisi peserta didik. Mulai tahun pelajaran 2013/2014 implementasi Kurikulum 2013 dengan pendekatan pembelajaran tematik mulai disosialisasikan oleh pemerintah bagi guru kelas I -VI oleh pemerintah. Akan tetapi pelaksanaan Kurikulum 2013 dengan pendekatan tematik di MI belum bisa dilaksanakan sepenuhnya.

Implementasi Kurikulum 2013 dengan pendekatan tematik di MI Muhammadiyah Selo Kulon Progo dilaksanakan secara bertahap dalam setiap kelas. Hasil wawancara dengan Kepala Madrasah pada tanggal 8 Agustus 2018 yang mengatakan bahwa implementasi kurikulum 2013 di MI Muhammadiyah Selo Kulon Progo sudah dimulai sejak tahun pelajaran 2016/2017 untuk kelas I dan IV, tahun pelajaran 2017/2018 untuk kelas I,II dan IV,V,dan untuk tahun pelajaran 2018/2019 sudah dilaksanakan semua kelas mulai dari kelas I sampai VI. ${ }^{8}$

Selain itu kepala madrasah juga menyatakan bahwa dalam mengimplementasikan Kurikulum 2013, MI Muhammadiyah Selo Kulon Progo menggunakan pendekatan tematik, tetapi untuk mata pelajaran Matematika dan Penjasorkes kelas IV sampai dengan kelas VI berdiri sendiri tidak masuk dalam pembelajaran tematik. Kepala madrasah juga menyatakan bahwa pembelajaran tematik diterapkan di madrasah ini agar peserta didik memiliki sikap dan keterampilan yang bagus. ${ }^{9}$

Selaras dengan kebijakan pemerintah Permendikbud RI Nomor 22 Tahun 2016 tentang standar proses pendidikan dasar dan menengah yang menyatakan bahwa prinsip pembelajaran tematik salah satunya yaitu peningkatan dan keseimbangan

8. Hasil wawancara dengan Bapak Suryono,S.Pd.I Kepala MI Muhammadiyah Selo Kulon Progo tanggal 8 Agustus 2018.

9. Hasil wawancara dengan Bapak Suryono,S.Pd.I Kepala MI Muhammadiyah Selo Kulon Progo tanggal 8 Agustus 2018. 
antara keterampilan fisikal (hardskill) dan keterampilan mental (softskill). ${ }^{10}$ Selain itu dalam Permendikbud RI Nomor 24 Tahun 2016 tentang Kompetensi Inti dan Kompetensi Dasar Pelajaran Kurikulum 2013 juga menyatakan bahwa pelaksanaan pembelajaran pada Sekolah Dasar/ Madrasah Ibtidaiyah (SD/MI) dilakukan dengan pendekatan pembelajaran tematik terpadu, kecuali untuk mata pelajaran Matematika dan Pendidikan Jasmani dan Olahraga Kesehatan sebagai mata pelajaran yang berdiri sendiri untuk kelas IV, V, VI. ${ }^{11}$

Dari pernyataan di atas dapat disimpulkan bahwa MI Muhammadiyah Selo Kulon Progo telah mengimplementasikan Kurikulum 2013 dengan menerapkan pembelajaran tematik dalam proses pembelajarannya. Meskipun hal ini dilakukan secara bertahap, mulai tahun pelajaran 2016/2017. Dan pada tahun pelajaran 2018/2019 madrasah ini telah mengimplementasikan kurikulum 2013 secara keseluruhan dari kelas I - VI. Proses implementasikan pembelajaran tematik tersebut meliputi 3 tahapan, yaitu:

Pertama, tahap perencanaan pembelajaran tematik. Tahap perencanaan dalam mengimplemetasikan pembelajaran tematik yang telah dilaksananakan oleh guru kelas V MI Muhammadiyah Selo Kulon Progo adalah mengambil tema dari Kemendikbud RI, mengecek/ melihat Standar Kompetensi Lulusan (SKL), Kompetensi Inti (KI), Kompetensi Dasar (KD), melakukan Pemetaan KI,KD, membuat jaringan tema, menyusun silabus, dan merancang RPP. Meskipun demikian ada dua bagian yang masih perlu disempurnakan diantaranya pada proses menetapkan tema guru masih mengambil/ meniru tema yang telah ditetapkan oleh Kementerian Pendidikan dan Kebudayaan RI tanpa ada upaya dari guru untuk mengkreasikan. Dalam proses ini guru perlu mengkreasikan tema supaya bisa disesuaikan dengan lingkungan dan kebutuhan peserta didik. Hal lain yang masih perlu disempurnakan juga adalah proses mengecek SKL,KI, dan KD. Sementara dalam proses ini guru harus menganalisis SKL,KI, dan KD, tidak hanya sekedar mengecek apa yang sudah ada, sehingga guru bisa sepenuhnya mengetahui apa saja yang harus dilakukan dalam pembelajaran supaya bisa memenuhi standar kompetensi kelulusan secara maksimal.

10. Salinan Lampiran Peraturan Menetri Pendidikan dan Kebudayaan Republik Indonesia Nomor 22 Tahun 2016 tentang Standar Proses Pendidikan Dasar dan Menengah. hlm 2.

11. Salinan Lampiran Peraturan Menetri Pendidikan dan Kebudayaan Republik Indonesia Nomor 24 Tahun 2016 tentang Kompetensi Inti dan Kompetensi Dasar Pada Kurikulum 2013 Pendidikan Dasar dan Menengah, hlm. 3. 
Kedua, tahap pelaksanaan pembelajaran tematik. Dalam tahap pelaksanaan ini meliputi tiga kegiatan, yaitu kegiatan pendahuluan, kegiatan inti, dan kegiatan penutup. Kegiatan pendahuluan yang dilaksanakan oleh guru kelas V MI Muhammadiyah Selo Kulon Progo yaitu, mengucapkan salam, mengajak peserta didik untuk berdoa bersama-sama, dan menanyakan kabar peserta didik pada hari itu sebagai upaya untuk menyiapkan fisik dan psikis peserta didik. Selain itu guru juga melakukan apersepsi dengan mengaitkan materi hari itu dengan pengalaman peserta didik, dan selalu menyampaikan tujuan pembelajaran yang akan dicapai. Dengan demikian dapat disimpulkan bahwa guru memiliki kemampuan untuk membuka pelajaran dalam pelaksanaan pembelajaran tematik.

Sementara itu untuk kegiatan inti dalam pembelajaran tematik di kelas V MI Muhammadiyah Selo Kulon Progo. Dalam kegiatan pembelajaran tematik di kelas guru menggunakan pendekatan saintifik yaitu, mengamati, menanya, mencoba/ mengasosiasi, menalar, dan mengkomunikasikan. Sementara itu dalam kegiatan pembelajaran tematik tersebut guru memanfaatkan lingkungan sekitar madrasah sebagai sarana pembelajaran. Strategi yang digunakan oleh guru adalah cooperative learning sebagai upaya guru untuk mengembangkan keterampilan sosial peserta didik. Dan dalam pelaksanaan kegiatan penutup guru membuat rangkuman dengan melibatkan peserta didik dengan bertanya kepada peserta didik apa saja yang telah dipelajari hari itu, dan menyimpulkannya. Akan tetapi guru tidak memberikan tindak lanjut kepada peserta didik dalam proses pembelajaran.

Ketiga, tahap evaluasi pembelajaran tematik. Tahap evaluasi dilaksanakan dengan menilai tiga aspek yaitu aspek sikap, aspek pengetahuan, dan aspek keterampilan. Penilain aspek sikap dilaksanakan guru dengan teknik observasi. Sedangkan untuk aspek pengetahuan dilakukan dengan tes tertulis, lisan maupun penugasan. Dan untuk aspek keterampilan dilakukan dengan praktik, portofolio, dan produk.

Adapun dari implementasi pembelajaran tematik di atas dapat dinyatakan bahwa kelebihan yang dimiliki oleh guru kelas V MI Muhammadiyah Selo Kulon Progo adalah guru memiliki keterampilan dalam membuka dan menutup pelajaran, keterampilan mengadakan variasi dengan menggunakan metode dan media pembelajaran keterampilan memanfaatkan lingkungan sebagai sumber belajar, dan keterampilan untuk membimbing diskusi kelompok. Sedangkan kelemahan guru yaitu rencana pelaksanaan pembelajaran tidak semuanya dibuat 
oleh guru itu sendiri sehingga dalam pelaksanaan pembelajaran terkadang guru tidak sesuai dengan apa yang direncanakan, guru tidak selalu mendokumentasikan hasil penilaiannya terhadap peserta didik terutama penilaian pada aspek sikap.

\section{Keterampilan Sosial Peserta Didik}

a. Keterampilan Bekerja Sama

Keterampilan bekerja sama sangat dibutuhkan dalam kehidupan bermasyarakat baik saat ini maupun masa depan. Hal ini karena keterampilan bekerja sama sangat menentukan bagi keberhasilan hubungan sosial seseorang termasuk peserta didik dalam proses pembelajaran. Kerjasama dalam belajar merupakan salah satu hal yang sangat penting dalam suatu proses pembelajaran. Apalagi dalam proses pembelajaran tematik yang mengacu pada kurikulum 2013, kemampuan bekerja sama dari peserta didik sangat dibutuhkan untuk mengembangkan kompetensi sikapnya.

Menurut hasil observasi yang dilakukan peneliti dalam pembelajaran tematik yang dilaksanakan di kelas V MI Muhammadiyah Selo Kulon Progo menunjukkan bahwa dalam setiap proses pembelajaran tematik guru selalu membagi peserta didik menjadi beberapa kelompok. Selain itu juga menunjukkan bahwa keterampilan bekerja sama diantara peserta didik sangat baik. Hal ini terlihat ketika proses pembelajaran tematik berlangsung dan guru meminta peserta didik untuk melaksanakan diskusi kelompok semua peserta didik langsung berkumpul menurut kelompoknya masing-masing. Dalam setiap kelompok tersebut terlihat setiap peserta didik mempunyai peran masingmasing dalam kelompoknya. ${ }^{12}$

Saat observasi pembelajaran tanggal 7 Agustus 2018 Tema Udara Bersih Bagi Kesehatan Sub Tema Cara Tubuh Mengolah Udara Bersih Pembelajaran ke-2 terlihat kegiatan diskusi kelompok yang semua anggota kelompoknya aktif. Saat itu guru memberi tugas pada setiap kelompok untuk membuat pertanyaan dengan kata tanya apa, di mana, kapan, bagaimana, dan mengapa. Dalam kelompoknya masing-masing terlihat peserta didik membagi tugas siapa yang membuat pertanyaan dengan kata tanya apa, siapa yang membuat pertanyaan dengan kata tanya di mana dan sebagainya. Karena satu kelompok

12. Hasil Observasi Keterampilan Sosial Peserta Didik dalam Pembelajaran Tematik Tema Udara Bersih Bagi Kesehatan Sub Tema Cara Tubuh Mengolah Udara Bersih Pembelajaran 3 di Kelas V MI Muhammadiyah Selo tanggal 8 Agustus 2018. 
hanya terdiri dari 4 peserta didik sementara kata tanya yang dipakai untuk membuat kalimat tanya yang ada 5 maka dalam kelompok itu sepakat untuk yang 1 kata tanya dikerjakan bersama. Dalam setiap kelompok juga terlihat jika ada peserta didik yang kesulitan dalam membuat kalimat tanya yang menjadi bagiannya, peserta didik yang lain berusaha membantu. ${ }^{13}$

Kerja sama yang lain yang ditunjukkan oleh peserta didik saat proses pembelajaran tematik berlangsung diantaranya adalah adanya pembagian tugas dalam setiap kelompok. Dari hasil observasi yang dilakukan peneliti menunjukkan ketika guru membagi kelas dalam kelompok-kelompok, setelah peserta didik duduk bersama dengan kelompoknya mereka selalu membagi tugas siapa yang menjadi sekretaris untuk menulis hasil diskusi kelompoknya. Selain itu juga dibagi tugas siapa nanti yang bertugas untuk mewakili kelompok membacakan hasil diskusinya. ${ }^{14}$ Jadi setiap anggota kelompok terlibat aktif dalam menyelesaikan tugas yang diberikan oleh guru. Kerja sama yang lain yang ditunjukkan oleh peserta didik dalam pembelajaran tematik adalah mereka berdiskusi, bermusyawarah dalam menyelesaikan tugas yang diberikan oleh guru.

Akan tetapi dalam kegiatan kelompok tersebut juga terlihat perilaku "mendominasi" dari salah satu peserta didik. Hal ini ditunjukkan dari sikap salah seorang peserta didik yang bernama Nadif Tian Ardiansyah yang selalu menyuruh temannya untuk menuruti kemauannya. Terlihat ketika dalam kelompok tersebut ada pembagian tugas dalam membuat kalimat tanya dengan kata tanya apa, mengapa, di mana, bagaimana, kapan dan Nadif Tian Ardiansyah mendapat bagian untuk membuat kalimat tanya dengan kata tanya bagaimana Nadif Tian Ardiansyah langsung menyuruh Evan Nur Hidayanto untuk mengerjakan apa yang menjadi tugasnya. ${ }^{15}$

13. Hasil Observasi Keterampilan Sosial Peserta Didik dalam Pembelajaran Tematik Tema Udara Bersih Bagi Kesehatan Sub Tema Cara Tubuh Mengolah Udara Bersih Pembelajaran ke-2 di Kelas V MI Muhammadiyah Selo tanggal 7 Agustus 2018;Dokumentasi RPP Tema Udara Bersih Bagi Kesehatan Sub Tema Cara Tubuh Mengolah Udara Bersih Pembelajaran 2.

14. Ibid.

15. Hasil Observasi Keterampilan Sosial Peserta Didik dalam Pembelajaran Tematik Tema Udara Bersih Bagi Kesehatan Sub Tema Cara Tubuh Mengolah Udara Bersih Pembelajaran ke-2 di Kelas V MI Muhammadiyah Selo tanggal 7 Agustus 2018. 
Dari hasil observasi lain menunjukkan adanya interaksi antara guru dengan peserta didik dan peserta didik yang satu dengan peserta didik yang lainnya. Hal ini terlihat ketika proses pembelajaran tematik di kelas V MI Muhammadiyah Selo Kulon Progo antara guru dan peserta didik selalu berkomunikasi untuk mencapai tujuan pembelajaran. Untuk meningkatkan interaksi antar peserta didik dalam setiap pembelajaran guru selalu meminta peserta didik untuk berdiskusi kelompok. Dalam diskusi kelompok tersebut dapat dilihat adanya interaksi diantara peserta didik. Peserta didik dalam kelompoknya berdiskusi untuk menyelesaikan tugas yang diberikan oleh guru. Ketika sedang berdiskusi terlihat peserta didik yang berperan sebagai sekretaris menulis setiap usulan yang disampaikan oleh teman. Sementara teman yang lain mendengarkan usulan itu dan kemudian mendiskusikannya bersama-sama. Hal ini menunjukkan adanya sikap menghargai pendapat orang lain. ${ }^{16}$

Dari aktivitas diskusi kelompok juga diketahui bahwa adanya kontak mata diantara peserta didik ketika sedang berbicara. Ketika ada teman atau kelompok yang lain yang sedang presentasi di depan kelompok lain menyimak apa yang menjadi hasil diskusinya. Saat guru memberikan tugas untuk melakukan wawancara dengan nara sumber dalam hal ini warga yang memproduksi gula jawa dan growol terlihat semua peserta didik antusias dan memerankan tugasnya masing-masing secara bersama-sama. Ada yang bertugas menulis hasil wawancara, dan ada yang bertugas bertanya kepada nara sumber. Hal ini menunjukkan bahwa peserta didik mampu melibatkan diri dalam kelompoknya. Dari tugas wawancara tersebut tampak ketika peserta didik mengajukan pertanyaan kepada nara sumber (pembuat gula jawa) menatap mata nara sumbernya. Hal ini menunjukkan adanya kontak mata dalam komunikasi mereka. ${ }^{17}$

Sementara itu dari hasil observasi yang lain menunjukkan bahwa peserta didik di kelas V MI Muhammadiyah Selo Kulon Progo mempunyai tingkat toleransi yang tinggi. Hal ini terlihat dari aktivitas kelompok yang menunjukkan

16. Hasil Observasi Keterampilan Sosial Peserta Didik dalam Pembelajaran Tematik Tema Udara Bersih Bagi Kesehatan Sub Tema Cara Tubuh Mengolah Udara Bersih Pembelajaran 3 di Kelas V MI Muhammadiyah Selo tanggal 8 Agustus 2018;Dokumentasi RPP Tema Udara Bersih Bagi Kesehatan Sub Tema Cara Tubuh Mengolah Udara Bersih Pembelajaran 3.

17. Ibid. 
adanya toleransi dalam mengerjakan dan menyelesaikan tugas kelompoknya, yaitu dengan memberi bantuan teman yang kesulitan dalam menyelesaikan tugasnya dalam kelompok tersebut. Hal ini dipertegas dengan hasil wawancara bersama salah satu peserta didik kelas V MI Muhammadiyah Selo Kulon Progo yang mengatakan bahwa sikap yang dilakukan oleh peserta didik ketika melihat orang lain dalam kesulitan peserta didik itu membantu dan menolong temannya. ${ }^{18}$ Dengan membantu dan menolong teman yang kesulitan tersebut menunjukkan bahwa peserta didik memiliki rasa kepedulian sosial terhadap peserta didik yang lain.

Hasil observasi keterampilan sosial peserta didik dalam pembelajaran di kelas V tanggal 14 Agustus 2018 menunjukkan bahwa saat pembelajaran berlangsung tiba-tiba ada salah seorang peserta didik yang bernama Hafidz Iskandar Firmansyah berkata “ Eh, gambarnya kayak bapaknya Evan ya?". Karena kebetulan gambar yang ada pada Buku Siswa tersebut memiliki kemiripan dengan ayah dari peserta didik yang diejek tersebut. Mendengar hal tersebut Evan langsung menangis karena memang di kelas itu Evan terkenal anak yang "cengeng". Dengan reaksi Evan yang menangis tadi tidak membuat Hafidz berhenti untuk mengejeknya justru Hafidz semakin semangat untuk mengejek Evan lagi dengan berkata "Halah, kayak gitu aja nangis!huh, cengeng!". Melihat hal tersebut guru langsung menasehati Hafidz untuk segera minta maaf dan tidak boleh mengulanginya lagi. ${ }^{19}$ Peristiwa tersebut menunjukkan bahwa ada perilaku "menggoda" dari salah satu peserta didik dengan mengejek temannya.

Senada dengan yang dijelaskan oleh Daniel Goleman bahwa setiap individu mempunyai pembawaan yang integral, seperti kerja sama, empati, dan sifat mementingkan kepentingan orang lain. ${ }^{20}$ Sementara itu Eggen dan Kauchack dalam Trianto menjelaskan bahwa pembelajaran kooperatif merupakan sebuah strategi pengajaran yang melibatkan peserta didik bekerja secara berkolaborasi

18. Hasil wawancara dengan Hafidz Iskandar Firmansyah Peserta Didik Kelas V MI Muhammadiyah Selo Kulon Progo 18 Agustus 2018.

19. "Hasil Observasi Keterampilan Sosial Peserta Didik dalam Pembelajaran Tematik di Kelas V MI Muhammadiyah Selo tanggal 14 Agustus 2018.

20. Muhaimin Akhmad Azzet, Mengembangkan Kecerdasan Sosial Bagi Anak (Yogyakarta: Katahati, 2014), hlm. 43-44. 
untuk mencapai tujuan bersama. ${ }^{21}$ Adapun tujuan pembelajaran kooperatif mencakup tiga hal, yaitu: hasil belajar akademik, penerimaan terhadap keragaman, dan pengembangan keterampilan sosial. ${ }^{22}$ Selain itu dengan belajar kooperatif akan muncul generasi baru yang memiliki prestasi akademik yang cemerlang dan memiliki solidaritas sosial yang kuat. ${ }^{23}$

Dari pernyataan di atas dapat disimpulkan bahwa keterampilan bekerja sama peserta didik dalam pembelajaran tematik di kelas V MI Muhammadiyah Selo Kulon Progo meliputi adanya diskusi untuk menyelesaikan masalah, pembagian tugas dalam kelompok, kemampuan peserta didik dalam melibatkan diri dalam kelompok, menghargai pendapat teman, membantu teman yang kesulitan, memperhatikan teman yang sedang berbicara, dan adanya kontak mata saat berbicara dengan orang lain. Akan tetapi dalam aktivitas kelompok tersebut juga ada sikap "mendominasi/ berkuasa" dari salah seorang peserta didik, dan juga perilaku "menggoda" dengan mengejek temannya.

b. Keterampilan Mengontrol Diri

Berbagai permasalahan yang sering muncul dalam kehidupan ini banyak diakibatkan oleh ketidakmampuan seseorang dalam mengontrol diri. Kemampuan untuk mengontrol diri merupakan salah satu bentuk kecerdasan moral. Kontrol diri merupakan kemampuan seseorang untuk mengendalikan dirinya sendiri agar tidak merugikan orang lain. Dalam kaitannya dengan pembelajaran di kelas kontrol diri atau pengendalian diri sangat diperlukan baik oleh guru maupun peserta didik. Karena dengan pengendalian diri yang baik akan menciptakan suasana kondusif dalam suatu proses pembelajaran.

Dari hasil observasi yang dilakukan peneliti terhadap keterampilan sosial peserta didik dalam pembelajaran tematik di kelas V MI Muhammadiyah Selo Kulon Progo menunjukkan peserta didik bertanggung jawab dalam menyelesaikan tugas yang diberikan oleh guru. Hal ini terlihat saat observasi pada tanggal 15 Agustus 2018, ketika guru meminta salah satu peserta didik untuk memimpin musyawarah di kelas sebagai salah satu tugas yang diberikan guru. Saat itu guru meminta salah satu peserta didik untuk memimpin jalannya

21. Trianto, Mendesain Model Pembelajaran Inovatif-Progresif (Jakarta: Prenada Media Group, 2011), hlm. 58.

22. Ibid., hlm. 59 .

23. Ibid., hlm. 56. 
musyawarah tentang cara menjaga kebersihan lingkungan kelas tanpa menunjuk salah satu nama peserta didik.

Saat itu terlihat kelas menjadi hening beberapa menit karena tidak ada satupun peserta didik yang maju untuk memimpin musyawarah. Peserta didik hanya saling pandang. Setelah guru menyampaikan kembali "ayo siapa yang mau memimpin musyawarah?", Hafidz kemudian berdiri dan maju di depan kelas melaksanakan tugas dari guru untuk memimpin jalannya musyawarah hari itu. Hal ini menunjukkan bahwa adanya tanggung jawab dari peserta didik dalam menyelesaikan tugas yang diberikan oleh guru. ${ }^{24} \mathrm{Hal}$ ini juga dipertegas dengan hasil wawancara dengan Hafidz Iskandar Firmansyah peserta didik kelas V MI Muhammadiyah Selo Kulon Progo yang menyatakan bahwa ketika peserta didik tersebut diberi tugas langsung dikerjakannya. ${ }^{25}$

Selain itu dari hasil observasi juga menunjukkan bahwa sebagian besar peserta didik mematuhi aturan yang telah dibuat oleh guru. Salah satu aturan yang dibuat oleh guru yaitu semua peserta didik harus mengerjakan tugas yang diberikan oleh guru baik di madrasah atau di rumah. Setiap dilakukan observasi oleh peneliti semua peserta didik antusias mengerjakan tugas yang diberikan oleh guru, akan tetapi ketika ada tugas yang harus dikerjakan di rumah ada beberapa peserta didik yang tidak mengerjakan tugas tersebut.

Sementara itu dari hasil observasi yang lain yang berkaitan dengan keterampilan mengontrol diri menunjukkan bahwa sebagian besar peserta didik tidak bisa mengatur waktu dalam menyelesaikan tugas yang diberikan oleh guru. Terbukti ketika guru memberikan tugas dan harus diselesaikan dalam tenggang waktu tertentu, lima dari delapan peserta didik tidak bisa menyelesaikan tugas tepat waktu. Dengan kata lain hanya ada tiga peserta didik yang mampu menyelesaikan tugas sesuai waktu yang telah ditetapkan oleh guru.

Senada dengan yang dijelaskan oleh Golfried dan Merbaum bahwa kontrol diri adalah suatu kemampuan untuk menyusun, membimbing, mengatur, dan mengarahkan bentuk perilaku yang dapat membawa individu ke arah konsekuensi positif. Kontrol diri juga menggambarkan keputusan individu

24. Hasil Observasi Keterampilan Sosial Peserta Didik dalam Pembelajaran Tematik di Kelas V MI Muhammadiyah Selo Kulon Progo tanggal 15 Agustus 2018.

25. Hasil wawancara dengan Hafidz Iskandar Firmansyah Peserta Didik Kelas V MI Muhammadiyah Selo Kulon Progo 18 Agustus 2018. 
yang melalui pertimbangan kognitif untuk menyatukan perilaku yang telah disusun untuk meningkatkan hasil dan tujuan tertentu seperti yang diinginkan. ${ }^{26}$ Selain itu John Jarolimek juga menyatakan bahwa Learning self-control and self direction meliputi mematuhi peraturan, tanggung jawab, dan tepat waktu. ${ }^{27}$

Dari pernyataan di atas dapat disimpulkan bahwa kemampuan mengontrol diri peserta didik dalam pembelajaran tematik di kelas V MI Muhammadiyah Selo Kulon Progo meliputi mematuhi peraturan yang dibuat guru, tanggung jawab, dan tepat waktu dalam menyelesaikan tugas. Dalam aspek kepatuhan terhadap aturan dan kedisiplinan waktu dalam menyelesaikan tugas, masih ada beberapa peserta didik yang perlu bimbingan, karena ada empat dari delapan peserta didik sering kehabisan waktu dalam menyelesaikan tugas. Oleh karena itu guru perlu lebih memaksimalkan usahanya untuk melatih kedisplinan dan kepatuhan peserta didik dalam proses pembelajaran.

c. Keterampilan Berbagi Pikiran dan Pengalaman dengan Orang Lain

Kunci utama dalam sebuah interaksi adalah adanya komunikasi. Banyak hal yang terjadi dalam interaksi tersebut. Dalam sebuah pembelajaran misalnya mereka saling berbagi cerita, saling bertukar pikiran, pengalaman, saling mengekspresikan dan juga saling bertukar pendapat. Setiap orang pasti punya pengalaman hidup yang berharga. Baik itu pengalaman yang menyenangkan ataupun pengalaman yang menyedihkan. Dengan berbagi pengalaman kepada orang lain pikiran kita akan menjadi terbuka.

Dari hasil observasi yang dilaksanakan oleh peneliti pada tanggal 6 Agustus 2018 menunjukkan bahwa keterampilan berbagi pikiran dan pengalaman peserta didik dalam pembelajaran tematik di kelas V MI Muhammadiyah Selo cukup baik. Hal ini terbukti ketika proses pembelajaran tematik di kelas guru meminta beberapa peserta didik untuk menceritakan apa yang mereka amati didepan kelas. Dengan antusias peserta didik maju di depan kelas dan menceritakan hasil pengamatannya. ${ }^{28}$

26. M. Nur dan Rini, Teori-Teori Psikologi (Yogyakarta: Ar-Ruzz Media, 2010), hlm. 22.

27. Enok Maryani, "Pengembangan Program Pembelajaran IPS Untuk Meningkatkan Keterampilan Sosial Siswa," Jurnal Penelitian, Vol. 9, No. 1, April 2019, hlm. 13.

28. Hasil Observasi Keterampilan Sosial Peserta Didik dalam Pembelajaran Tematik di Kelas V MI Muhammadiyah Selo tanggal 6 Agustus 2018. 
Selain itu dari hasil observasi yang sama juga menunjukkan bahwa peserta didik berani menyampaikan pendapatnya. Bukti dari pernyataan tersebut adalah ketika guru meminta peserta didik menyampaikan hasil diskusi kelompoknya, semua peserta didik bersedia menjadi wakil dari kelompoknya masing-masing untuk menyampaikan pendapatnya. Ketika guru meminta wakil dari masingmasing kelompok untuk menyampaikan hasil diskusinya terlihat ada salah satu peserta didik yang berani mengkritik atau menyanggah hasil diskusi kelompok lain. ${ }^{29}$ Dari hal itu menunjukkan bahwa peserta didik berani menyampaikan pendapatnya.

Hal ini dipertegas dengan hasil wawancara dengan Rahsti Cahya Ramadhani peserta didik kelas V MI Muhammadiyah Selo Kulon Progo yang menunjukkan keterampilan sosial peserta didik aspek keberanian dalam mengajukan pertanyaan menunjukkan adanya keberanian dari peserta didik untuk mengajukan pertanyaan kepada orang lain atas apa yang mereka belum pahami. ${ }^{30}$

Pernyataan tersebut di atas terbukti dari hasil observasi yang menunjukkan bahwa peserta didik berani mengajukan pertanyaan kepada orang lain. Ketika guru memberikan tugas kepada peserta didik untuk wawancara kepada narasumber dalam hal ini warga sekitar madrasah tentang kegiatan ekonomi masyarakat, dengan semangat peserta didik segera melaksanakan tugas tersebut. Secara bergantian dalam kelompoknya setiap peserta didik bertanya tentang apa yang ingin mereka ketahui sesuai dengan apa yang telah ada dalam daftar pertanyaan mereka. ${ }^{31}$ Dalam mengajukan pertanyaan kepada narasumber dilakukan dengan tegas tanpa ada rasa ragu-ragu dari peserta didik.

Sementara itu keterampilan sosial peserta didik jika dilihat dari aspek mengklarifikasi jawaban dari hasil observasi saat pembelajaran tematik menunjukkan bahwa hanya ada beberapa peserta didik yang mau dan berani mengklarifikasi atau menawarkan untuk menjelaskan tentang permasalahan

29. Hasil Observasi Keterampilan Sosial Peserta Didik dalam Pembelajaran Tematik di Kelas V MI Muhammadiyah Selo tanggal 7 Agustus 2018.

30. Hasil wawancara dengan Rahsti Cahya Ramadhani peserta didik kelas V MI Muhammadiyah Selo Kulon Progo pada tanggal 18 Agustus 2018.

31. Hasil Observasi Keterampilan Sosial Peserta Didik dalam Pembelajaran Tematik di Kelas V MI Muhammadiyah Selo Kulon Progo tanggal 8 Agustus 2018. 
yang mereka hadapi. Dari beberapa kali observasi peneliti hanya melihat satu peserta didik yang berani atau mau mengklarifikasi pendapat atau jawabannya. ${ }^{32}$

Selaras dengan yang dijelaskan oleh John Jarolimek bahwa keterampilan sosial aspek sharing ideas an experience with others meliputi berani menyampaikan pendapat, berani mengajukan pertanyaan, dan menawarkan untuk menjelaskan atau mengklarifikasi. ${ }^{33}$ Sementara itu menurut Gresham, Sugai, dan Horner bahwa akademic skills meliputi mencermati pemahaman orang dan mengajukan pertanyaan yang sesuai, menjaga keterangan dengan jarak yang tepat, dan meminta arahan atau bantuan. Untuk assertion skills meliputi mencermati pemahaman seseorang dan mengajukan pertanyaan, menawarkan untuk menjelaskan atau mengklarifikasi. ${ }^{34}$

Dari uraian di atas dapat disimpulkan bahwa kelebihan keterampilan sosial peserta didik meliputi adanya keterlibatan peserta didik dalam kelompok, menghargai pendapat teman, menawarkan bantuan kepada orang lain, memperhatikan teman yang berbicara, dan adanya kontak mata saat berbicara. Selain itu juga adanya tanggung jawab dalam menyelesaikan tugas, mematuhi peraturan yang ada, berani menyampaikan pendapat dan berani mengajukan pertanyaan kepada orang lain. Sedangkan kelemahan keterampilan sosial peserta didik diantaranya adalah adanya sikap "mendominasi" dalam kelompok, dan sikap "menggoda" teman yang lain serta kemampuan dalam mengatur waktu.

Oleh karena itu dapat disimpulkan bahwa adanya keterkaitan antara keterampilan sosial peserta didik dengan keterampilan guru dalam mengajar. Ketika perencanakan pembelajaran belum sepenuhnya dirancang sendiri oleh guru, tujuan yang dirumuskan dalam pemilihan model pembelajaran yang ditentukan belum semuanya mengarah pada pengembangan keterampilan sosial peserta didik. Ketika pelaksanaan pembelajaran yang dilakukan guru mengarah pada student center hal itu dapat mengembangkan keterampilan sosial peserta didik dengan menggunakan strategi pembelajaran cooperatif learning. Penilaian hasil pembelajaran peserta didik yang belum didokumentasikan

32. Hasil Observasi Keterampilan Sosial Peserta Didik dalam Pembelajaran Tematik di Kelas V MI Muhammadiyah Selo tanggal 7 Agustus 2018.

33. Enok Maryani, "Pengembangan Program Pembelajaran IPS Untuk Meningkatkan Keterampilan Sosial Siswa," Jurnal Penelitian. Vol. 9, No. 1, April 2019, hlm 13.

34. Smith dan Bremer, "Teaching Social Skill," International Center on Secondary Education and Transition Information Brief, Vol. 3, No. 5, Oktober 2004, hlm. 1. 
secara keseluruhan mengakibatkan guru tidak bisa mengetahui perkembangan keterampilan sosial peserta didik secara terperinci dan jelas.

\section{Faktor Pendukung dan Penghambat Pengembangan Keterampilan Sosial Peserta Didik}

a. Faktor Pendukung

Keberhasilan suatu proses pembelajaran ditentukan oleh beberapa faktor. Faktor yang menjadi penentu keberhasilan suatu proses pembelajaran diantaranya adalah guru, peserta didik, dan lingkungan. Dari faktorfaktor tersebut sangat mempengaruhi hasil yang dicapai dari sebuah proses pembelajaran yang dilaksanakan.

Dari hasil wawancara dengan guru kelas V MI Muhammadiyah Selo Kulon Progo diketahui bahwa guru tersebut mulai mengajar sejak tahun 1999. ${ }^{35}$ Itu berarti guru kelas V di MI Muhammadiyah Selo Kulon Progo telah berpengalaman dalam mengajar. Sembilan belas tahun adalah waktu yang cukup lama untuk bisa mengetahui dan memahami karakteristik peserta didik. Sehingga bisa dipastikan dengan bekal pengalaman yang cukup lama tersebut guru mempunyai kemampuan yang cukup dalam mengembangkan keterampilan sosial peserta didik. Selain itu dari hasil wawancara juga diketahui bahwa guru kelas V MI Muhammadiyah Selo Kulon Progo merupakan lulusan S-1 PGMI di UIN Sunan Kalijaga Yogyakarta. ${ }^{36}$ Hal tersebut menunjukkan bahwa ijazah yang dimiliki oleh guru kelas $\mathrm{V}$ sudah linier dengan tugasnya sebagai guru kelas, sehingga mampu menjalankan tugasnya dengan maksimal. Sebagian besar guru-guru di MI berijazah PAI sementara mereka harus melaksanakan tugas sebagai guru kelas. Hal itu menyebabkan mereka kurang menguasai dengan apa yang mereka ajarkan.

Dari hasil dokumentasi dan wawancara yang lain juga diketahui bahwa guru kelas V MI Muhammadiyah Selo telah bersertifikat pendidik sejak 2010. ${ }^{37}$ Dengan kata lain guru tersebut sudah profesional. Sementara itu dalam rangka mengimplementasikan Kurikulum 2013 semua guru di madrasah ibtidaiyah

35. Hasil wawancara dengan Ibu Puji Astuti,S.Pd.I guru kelas V MI Muhammadiyah Selo Kulon Progo tanggal 16 Agustus 2018.

36. Ibid.; Dokumentasi Ijazah Terakhir Guru Kelas V MI Muhammadiyah Selo Kulon Progo tanggal 16 Agustus 2018.

37. Ibid.; Dokumentasi Sertifikat Pendidik Guru Kelas V MI Muhammadiyah Selo Kulon Progo tanggal 16 Agustus 2018. 
se-Kulon Progo telah mendapatkan bimbingan teknis tentang implementasi pembelajaran tematik kurikulum 2013 pada tahun 2014 yang lalu. ${ }^{38}$ Sementara itu dari hasil observasi menunjukkan bahwa peserta didik di Kelas V MI Muhammadiyah Selo Kulon Progo memiliki motivasi belajar yang tinggi. Hal ini ditunjukkan dari antusiaisme peserta didik dalam mengikuti pelajaran di kelas. Terlihat keseriusan peserta didik dalam belajar dan menyelesaikan tugastugas yang diberikan oleh guru. ${ }^{39}$

Selain dari dua faktor tersebut lingkungan juga sangat berpengaruh dalam pengembangan keterampilan sosial peserta didik dalam pembelajaran. Hal ini dipertegas dengan hasil wawancara dengan dengan guru kelas V MI Muhammadiyah Selo Kulon Progo yang menyatakan bahwa lingkungan madrasah mendukung untuk mengembangkan keterampilan peserta didik dalam proses pembelajaran. ${ }^{40}$ Dari hasil observasi juga menunjukkan bahwa lingkungan MI Muhammadiyah Selo Kulon Progo kondusif untuk proses pembelajaran. ${ }^{41}$

Senada dengan yang diamanatkan dalam Peraturan Pemerintah Nomor 19 Tahun 2005 bab VI pasal 29 tentang Standar Pendidik dan Tenaga Kependidikan menyatakan bahwa pendidik pada SD/MI, atau bentuk lain yang sederajat memiliki kualifikasi akademik pendidikan minimum diploma empat (D-IV) atau sarjana (S1); latar belakang pendidikan tinggi di bidang pendidikan SD/ MI, kependidikan lain, atau psikologi; dan sertifikat profesi guru untuk SD/ MI. ${ }^{42}$

Dari uraian di atas dapat disimpulkan bahwa dalam mengembangkan keterampilan sosial peserta didik dalam pembelajaran tematik di kelas V MI Muhammadiyah Selo Kulon Progo yang menjadi faktor pendukung diantaranya adalah guru, peserta didik, dan lingkungan. Dari faktor guru yaitu kualifikasi sudah terpenuhi dan revelan dengan tugas, berpengalaman dalam mengajar,

38. Hasil wawancara dengan Ibu Puji Astuti,S.Pd.I guru kelas V MI Muhammadiyah Selo Kulon Progo tanggal 16 Agustus 2018.

39. Hasil Observasi Keterampilan Sosial Peserta Didik dalam Pembelajaran Tematik Tema Udara Bersih Bagi Kesehatan Sub Tema Cara Tubuh Mengolah Udara Bersih Pembelajaran 3 di Kelas V MI Muhammadiyah Selo tanggal 8 Agustus 2018.

40. Hasil wawancara dengan Ibu Puji Astuti,S.Pd.I guru kelas V MI Muhammadiyah Selo Kulon Progo tanggal 16 Agustus 2018.

41. Hasil Observasi Lokasi MI Muhammadiyah Selo Kulon Progo tanggal 21 Agustus 2018.

42. Peraturan Pemerintah Nomor 19 Tahun 2005 tentang Standar Nasioanal Pendidikan. 
dan professional. Sementara dari faktor peserta didik dan lingkungan adalah adanya motivasi belajar yang tinggi, dan lingkungan yang kondusif.

b. Faktor Penghambat

Selain faktor-faktor pendukung yang telah diuraikan di atas, tentunya ada juga faktor-faktor yang menghambat atau menghalangi pengembangan keterampilan peserta didik dalam pembelajaran tematik. Adapun yang menjadi faktor penghambat dalam pengembangan keterampilan peserta didik dalam pembelajaran tematik di kelas V MI Muhammadiyah Selo Kulon Progo akan diuraikan dibawah ini.

Dari hasil wawancara dengan guru kelas V MI Muhammadiyah Selo Kulon Progo menunjukkan hambatan atau kendala yang dihadapi dalam mengembangkan keterampilan sosial peserta didik dalam pembelajaran tematik. adalah kurangnya sarana prasarana atau media pembelajaran yang mendukung, salah satu contohnya ketika saya membutuhkan proyektor untuk memutarkan video pembelajaran bagi anak-anak harus bergantian dengan guru yang lain karena madrasah hanya memiliki satu LCD. Selain itu juga distribusi sumber belajar yang agak lamban, dan adanya revisi Buku Guru dan Buku Siswa setiap tahun". ${ }^{43}$

Menurut Undang-Undang Sistem Pendidikan Nasional Nomor 20 Tahun 2003 Bab XII Pasal 45 tentang Sarana dan Prasana Pendidikan berbunyi setiap satuan pendidikan formal dan non formal menyediakan sarana dan prasarana yang memenuhi keperluan pendidikan sesuai dengan pertumbuhan dan perkembangan potensi fisik, kecerdasan intelektual, sosial, emosional, dan kejiwaan peserta didik. ${ }^{44}$

Dari pernyataan di atas dapat disimpulkan bahwa yang menjadi faktor penghambat dalam mengembangkan keterampilan peserta didik dalam pembelajaran tematik di kelas V MI Muhammadiyah Selo Kulon Progo adalah kurangnya sarana prasana yang mendukung bagi terlaksananya pengembangan keterampilan sosial peserta didik. Salah satu contohnya adalah kurangnya media pembelajaran proyektor yang dapat menunjang proses pembelajaran. Faktor

43. Hasil wawancara dengan Ibu Puji Astuti,S.Pd.I guru kelas V MI Muhammadiyah Selo Kulon Progo tanggal 9 Agustus 2018.

44. Undang-Undang Sistem Pendidikan Nasional Nomor 20 Tahun 2003 Bab XII Pasal 45 tentang Sarana dan Prasana Pendidikan. 
penghambat yang lain adalah distribusi sumber belajar yang agak lambat, dan adanya revisi Buku Guru dan Buku Siswa setiap tahun.

\section{Dampak Pengembangan Keterampilan Sosial Peserta Didik}

Keterampilan sosial merupakan modal utama seseorang untuk dapat menyesuaikan diri dengan lingkungan sosialnya. Dengan memiliki keterampilan sosial yang baik, seseorang akan mampu berinteraksi dengan keluarga, teman, dan lingkungan sosialnya. Oleh karena itu keterampilan sosial memiliki peran yang sangat penting dalam kehidupan seseorang. Karena dengan keterampilan sosial yang baik seseorang dapat berperan dan membawa dirinya dalam lingkungan kehidupan sosial mereka.

Dampak dari pengembangan keterampilan sosial yang dilaksanakan di MI Muhammadiyah Selo Kulon Progo muncul dalam sikap peserta didik yang dijelaskan secara rinci sebagai berikut:

Pertama, disiplin. Pada dasarnya manusia hidup di dunia memerlukan suatu norma aturan sebagai pedoman dan arahan untuk jalan kehidupan, demikian pula di madrasah perlu adanya tata tertib untuk berlangsungnya proses belajar yang tinggi maka dia harus mempunyai kedisiplinan belajar yang tinggi. Oleh karena itu seorang peserta didik dalam kegiatan pembelajaran di madrasah tidak akan lepas dari berbagai peraturan dan tata tertib yang diberlakukan di madrasahnya.

Sikap disiplin peserta didik sebagai dampak pengembangan keterampilan sosial di MI Muhammadiyah Selo Kulon Progo di antaranya adalah disiplin dalam berpakaian, disiplin waktu, dan disiplin dalam belajar. Dari hasil observasi menunjukkan bahwa semua peserta didik berpakaian seragam sesuai jadwal pemakaiannya. Tidak ada satu pun peserta didik yang memakai seragam tidak sesuai jadwal. Sikap disiplin lain yang ditunjukkan oleh peserta didik adalah disiplin waktu. Semua peserta didik kelas V datang ke madrasah tepat waktu. Sebelum pukul 07.00 WIB mereka sudah berada di madrasah. ${ }^{45}$ Adapun yang dilakukan guru melatih sikap disiplin ini adalah dengan membuat daftar urutan kedatangan peserta didik. Dan bagi peserta didik yang datang urutan nomor 1 mendapatkan tambahan bintang dari guru.

Kedua, tanggung jawab. Setiap peserta didik harus menanamkan rasa tanggung jawab pada diri masing-masing. Wujud dari bentuk sikap tanggung

45. Hasil Observasi Kegiatan Peserta Didik MI Muhammadiyah Selo Kulon Progo tanggal 8 Agustus 2018. 
jawab peserta didik kelas V MI Muhammadiyah Selo Kulon Progo berdasarkan hasil observasi yang dilaksanakan peneliti diantaranya yaitu setiap peserta didik melaksanakan jadwal piket untuk membersihkan kelas. Hal ini terlihat dari adanya pembagian tugas dalam piket tersebut, ada yang bertugas menyapu lantai dan ada yang bertugas menghapus papan tulis.

Selain itu peserta didik juga mengerjakan tugas yang diberikan oleh guru saat proses pembelajaran berlangsung. Ketika guru memberikan tugas untuk dikerjakan, peserta didik langsung mengerjakannya. Bentuk tanggung jawab yang lain yang dilaksanakan oleh peserta didik sebagai damapak dari pengembangan keterampilan sosial adalah selalu mengikuti upacara bendera yang dilaksanakan di madrasah. ${ }^{46}$ Saat upacara berlangsung tidak ada satupun peserta didik yang tidak mengikuti upacara, semua peserta didik mengikuti upacara bendera di halaman madrasah. Hal ini menunjukkan bahwa pengembangan keterampilan sosial memberikan kontribusi positif terhadap pelaksanaan tanggung jawab peserta didik di MI Muhammadiyah Selo Kulon Progo.

Ketiga, peduli terhadap teman. Sebagai manusia kita harus peduli terhadap sesama manusia karena selain makhluk individu, manusia juga sebagai makhluk sosial yang memerlukan orang lain untuk berinteraksi dan berkomunikasi. Dengan membangun kepedulian terhadap orang lain kita bisa memiliki kemampuan untuk berempati kepada orang lain, turut merasakan apa yang dirasakan oleh orang lain.

Dari hasil observasi yang dilakukan oleh peneliti tanggal 8 Agustus 2018 menunjukkan bahwa peserta didik memiliki sikap peduli terhadap teman. Hal ini terbukti dari sikap peserta didik ketika ada salah satu teman di kelasnya yang selama 3 hari tidak masuk sekolah karena sakit, mereka kemudian mengambil sikap mengumpulkan dana untuk menjenguk temannya tersebut. ${ }^{47}$ Selain hal itu sikap yang ditunjukkan oleh peserta didik sebagai bentuk kepedulian terhadap teman adalah dengan memberikan pinjaman pensil dan penggaris saat proses pembelajaran berlangsung. Hal ini dikarenakan ada salah satu peserta didik yang tidak membawa penggaris, sementara saat pelaksanaan pembelajaran tersebut membutuhkan penggaris.

46. Hasil Observasi Keterampilan Sosial Peserta Didik dalam Pembelajaran Tematik di Kelas V MI Muhammadiyah Selo tanggal 6 Agustus 2018.

47. Hasil Observasi Kegiatan Peserta Didik MI Muhammadiyah Selo Kulon Progo tanggal 30 Agustus 2018. 


\section{SIMPULAN}

Kesimpulan dari penelitian ini menunjukkan bahwa implementasi pembelajaran tematik di kelas $\mathrm{V}$ dilaksanakan dengan melalui tiga tahapan yaitu: pertama, tahap perencanaan yang meliputi mengambil tema dari Kemendikbud RI, mengecek/ melihat Standar Kompetensi Lulusan (SKL), Kompetensi Inti (KI), Kompetensi Dasar (KD), melakukan Pemetaan KI,KD, membuat jaringan tema, menyusun silabus, dan merancang RPP. Kedua, tahap pelaksanaan meliputi kegiatan pendahuluan, kegiatan inti, dan kegiatan penutup, dan ketiga, tahap evaluasi yang meliputi penilain kompetensi sikap, kompetensi pengetahuan, dan kompetensi keterampilan.

Keterampilan sosial peserta didik di kelas V MI Muhammadiyah Selo Kulon Progo yang sudah ditumbuhkan yaitu: pertama keterampilan bekerja sama dengan orang lain meliputi keterlibatan peserta didik dalam kelompok, menghargai pendapat teman, menawarkan bantuan kepada orang lain, memperhatikan teman yang berbicara, dan adanya kontak mata saat berbicara. Kedua, keterampilan mengontrol diri meliputi tanggung jawab dalam menyelesaikan tugas dan mematuhi peraturan yang ada. Ketiga, keterampilan berbagi pikiran dan pengalaman dengan orang lain meliputi berani menyampaikan pendapat dan berani mengajukan pertanyaan kepada orang lain.

Faktor pendukung dalam pengembangan keterampilan sosial peserta didik dalam pembelajaran kelas $\mathrm{V}$ adalah guru, peserta didik, dan lingkungan. Faktor guru meliputi kualifikasi S1 yang revelan dengan tugasnya, berpengalaman dalam mengajar, dan profesional. Faktor pendukung dari peserta didik dan lingkungan yaitu motivasi belajar yang tinggi, dan lingkungan yang kondusif untuk pembelajaran. Faktor penghambatnya yaitu kurangnya sarana prasana yang mendukung bagi terlaksananya pengembangan keterampilan sosial peserta didik, distribusi sumber belajar yang terlambat, dan masih adanya revisi sumber belajar dalam setiap tahunnya. Dampak dari pengembangan keterampilan sosial peserta didik diantaranya adalah munculnya sikap disiplin, tanggung jawab, dan peduli terhadap teman dari peserta didik.

Agar pelaksanaan pengembangan keterampilan sosial peserta didik dapat berjalan dengan maksimal sebaiknya guru lebih kreatif dalam merencanakan dan melaksanaan kegiatan pembelajaran. Selain itu kepala madrasah hendaknya terus melakukan pembinaan, pengawasan, dan evaluasi bagi guru dalam mengelola pembelajaran dengan cara mengadakan pertemuan rutin dengan guru untuk membahas pelaksanaan pembelajaran di kelas. 


\section{E. DAFTAR PUSTAKA}

Azzet, Muhaimin Akhmad. Mengembangkan Kecerdasan Sosial Bagi Anak. Yogyakarta: Katahati, 2014.

Lexy J, Moleong. Metodologi Penelitian Kualitatif. Bandung: PT. Remaja Rosdakarya, 2009.

Maryani, Enok. "Pengembangan Program Pembelajaran IPS Untuk Meningkatkan Keterampilan Sosial Siswa.” Jurnal Penelitian 9, no. 1 (April 2019).

Nur, M, dan Rini. Teori-Teori Psikologi. Yogyakarta: Ar-Ruzz Media, 2010.

Peraturan Menetri Pendidikan dan Kebudayaan Republik Indonesia Nomor 22 Tahun 2016 tentang Standar Proses Pendidikan Dasar dan Menengah, 2016.

Peraturan Menetri Pendidikan dan Kebudayaan Republik Indonesia Nomor 24 Tahun 2016 tentang Kompetensi Inti dan Kompetensi Dasar Pada Kurikulum 2013 Pendidikan Dasar dan Menengah, 2016.

Rosalina, Rossi, Marzuki, dan Mastar Asran. "Aplikasi Pembelajaran Tematik dalam Pengembangan Keterampilan Sosial dan Manajemen Perilaku Diri di Kelas I." Jurnal Pendidikan dan Pembelajaran 4, no. 8 (Agustus 2015). http:// jurnal.untan.ac.id/index.php/jpdpb/article/view/11110/10559.

Smith, dan Bremer. "Teaching Social Skill." International Center on Secondary Education and Transition Information Brief 3, no. 5 (2004).

Peraturan Pemerintah Nomor 19 Tahun 2005 tentang Standar Nasional Pendidikan, 2005.

Trianto. Mendesain Model Pembelajaran Inovatif-Progresif. Jakarta: Prenada Media Group, 2011.

Undang-Undang Republik Indonesia Nomor 14 Tahun 2005 tentang Guru dan Dosen, 2005.

Undang-Undang Sistem Pendidikan Nasional Nomor 20 Tahun 2003 Bab XII Pasal 45 tentang Sarana dan Prasana Pendidikan, 2003.

Utomo, Hardi. "Kontribusi soft skill dalam Menumbuhkan Jiwa Kewirausahaan." Jurnal Among Makarti 3, no. 5 (2010).

Zamroni. Pendidikan dan Demokrasi dalam Transisi (Prakondisi menuju Era Globalisasi). Jakarta: PSAP, 2007. 
